\title{
Crop growth, carbon sequestration and soil erosion in an organic vineyard of the Villány Wine District, Southwest Hungary
}

\author{
József DEZSŐ', DéNes LÓCZY ${ }^{1}$, Marietta REZSEK ${ }^{2}$, Roman HÜPPI ${ }^{3}$, \\ JÁNOs WERNER ${ }^{4}$ and LÁszLó HORV ÁTH ${ }^{5}$
}

\begin{abstract}
A more resilient adaptation to changing climate calls for crop diversification in vineyards, too. As a contribution to the H2020 collaborative project of the European Union, called Diverfarming, and part of the agroecological experiments during 2018 and 2019, grapevine biomass growth was monitored in connection with carbon storage types in soil and in the deposits removed by soil erosion. Phenometry was carried out interpreting segmented images to follow changes in biomass. It was found that crop growth could be best described by the Richards growth function. The distinction between grapevine and intercrop growth, however, requires further refinement in image analysis. In the laboratory TOC and $\mathrm{N}_{\text {total }}$ were measured for both the soil and the plant organs as well as for the eroded sediments. Greenhouse gas emissions and photosynthesis were monitored. Looking at the change of Leaf Area Index (LAI) over the growing period, image analysis pointed out the role of cut shoots from pruning in the $\mathrm{C}$ and $\mathrm{N}$ cycles. Maximum leaf area (at ripening) for guyot cultivation technique was extimated at $7,840 \mathrm{~m}^{2} \mathrm{ha}^{-1}$. Soil loss by erosion was established by sediment traps at the end of vinestock rows. The grain size distribution analysis led to the remarkable result that as erosion proceeded, the ratio of the sand fraction increased but remained within the range for the textural class of loam. Organic matter contents grew to $38 \mathrm{~g} \mathrm{~kg}^{-1}$. The rate of soil erosion is higher in ploughed than in grassed interrows by orders of magnitude.
\end{abstract}

Keywords: crop diversification, organic vineyard, phenometry, Leaf Area Index, C/N ratio, carbon sequestration, biomass, image analysis, soil erosion

Received April 2020; Accepted May 2020

\section{Introduction}

A major actual challenge for agriculture is the establishment of sustainable cultivation technologies without yield or income loss. The Horizon 2020 collaborative project Diverfarming (Crop diversification and low-input farming across Europe: from practition- ers' engagement and ecosystems services to increased revenues and value chain organisation) strives to increase the long-term resilience, ecological sustainability and economic revenues in many branches of agriculture across the EU (EIP-AGRI 2020). This objective is to be achieved through raising the provision level of ecosystem services, assessing

\footnotetext{
${ }^{1}$ Institute of Geography and Earth Sciences, University of Pécs, H-7624 Pécs, Ifjúság útja 6. Hungary.

E-mails: dejozsi@gamma.ttk.pte.hu, loczyd@gamma.ttk.pte.hu

${ }^{2}$ Doctoral School of Earth Sciences, University of Pécs, H-7624 Pécs, Ifjúság útja 6. Hungary.

E-mail: rezsekmaja@gmail.com

${ }^{3}$ Sustainable Agroecosystems, Institute of Agricultural Sciences, Department of Environmental Systems Science,

Swiss Institute of Technology (ETH Zürich), Universitätstrasse 2, CH-8092 Zurich, Switzerland.

E-mail: roman.hueppi@usys.ethz.ch

${ }^{4}$ Gere Attila Winery, H-7773 Villány, Erkel Ferenc u. 2/a. Hungary. E-mail: werner.janos@gere.hu

${ }^{5}$ Greengrass Atmospheric Environment Expert Ltd., H-2030 Érd, Kornélia utca 14/a. Hungary.

E-mail: horvath.laszlo.dr@gmail.com
} 
the real benefits and minimizing the limitations, barriers and drawbacks of diversified cropping systems under low-input practices. Tailor-made sustainable solutions are sought for six European pedoclimatic regions. In the Pannonian pedoclimatic region, the Hungarian partners run case studies in horticulture (an asparagus field) and in the vineyard of Gere Attila Winery. Some early results from the latter are presented here.

Crop growth should be monitored in response to environmental factors varying with time. The growing period of grapevine can be divided into three sections:

- Fruit set, when it is decided what portion of the grape inflorescence will develop into berries;

- Veraison ("change of colour"), i.e. the onset of sugar accumulation and rapid berry pigmentation by anthocyanins in red grapes;

- Berry ripening, synthesis of a high diversity of aroma compounds mostly to the effect of hormones and ethylene (KuHN, N. et al. 2014).

Castellarin, S.D. et al. (2007) claim that in the early growth period water deficit accelerates the process of sugar accumulation and induces anthocyanin synthesis and even after veraison increases anthocyanin accumulation. Water deficit negatively affects berry size (OJEDA, H. et al. 2001), but Greer, D.H. and Weston, C. (2010) confirm that moderate water deficit, UV-B radiation, and low temperatures positively affect ripening by increasing the content of total soluble solids and anthocyanins, while high temperatures, shade, and pathogens hinder ripening. Temperature rise is manifested in the sensory traits of berries and this is relevant for wine-making (Vilanova, M. and Soto, B. 2005; SAdras, V.O. et al. 2013). The responses to heat stress, however, vary with cultivar and season.

In each period the efficiency of assimilation of the canopy is a vital factor (DeLrot, S. et al. 2010). In modern viticulture crop and canopy growth are strictly regulated in the production of appelation wines (MATTHIASSON, S. 2013). If yield is restricted, the vegetative growth of vinestocks is promoted. Bunch spacing or cluster thinning is a common practice in many vineyards worldwide (NAOR, A. et al. 2002; LókINCZ, A. et al. 2003; Creation Wines 2014). The common goals meant to be achieved by yield restriction are higher alcohol levels, darker colour, riper fruit, reduced greenness and acidity, modified tannic composition - properties which are, however, not desirable for all wine varieties.

The quantitative and qualitative parameters of canopy do not only influence yields but also the carbon cycle and carbon sequestration in soils (MARras, S. et al. 2015; Nistor, E. et al. 2018). Insolation, air humidity, wind and other meteorological parameters modify vine canopy development and assimilation. Medium or long-term biomass accumulation in the soil is a function of canopy management practised to obtain a vegetative balance, i.e. to avoid exaggerated shoot growth.

Climate change mitigation is a major ecosystem service of vineyards. The principal greenhouse gas (GHG) in vineyards is $\mathrm{N}_{2} \mathrm{O}$ - with equally harmful effects as excessive $\mathrm{CO}_{2}$. The optimal timing of nitrogen fertilizer application can reduce the impact (NENDEL, C. and Kersebaum, K.C. 2004; Longbottom, M.R. and Petrie, P.R. 2015). Carbon is contained in all organs of grapes as well as in soil organic matter. Carbon sequestration in soil through minimized tillage, compost/mulch application and reduced factor passing can only be detected after many years (WoLfF, M. et al. 2013). Recently, cover crops have been used to reduce GHG emissions, but in certain environments, like the Mediterranean region, there may be severe competition for resources (Celette, F. et al. 2008). Recent studies, however, show that intercrops do not increase water stress compared to baresoil vineyards (Delpuech, X. and Metay, A. 2018). Nevertheless, on shallow soils decreased yields can be expected as the cover crop coverage is increased above a threshold (of 30\% in the Mediterranean region of France). The Mediterranean trend of climate change makes these observations relevant for Hungary. 
The rate of canopy development from April to June varies from year to year and exerts a decisive influence on the oncoming phenophase. The net assimilation and transpiration rates of grape canopy are a decisive factor in determining yield and grape juice quality (Kozma, P. 2001, 2002). The Leaf Area Index (LAI), i.e. the ratio of leaf area to cropping area, is a widely used indicator of the rate of photosynthesis and transpiration (Fuentes, S. et al. 2014). To determine LAI using the point quadrant (PQ) method is widespread in wine regions (SILVESTRONI, O. et al. 2018) as a standard analysis (WILsON, J.W. 1963; SMART, R. and Robinson, M. 1991). Hyperspectral images of Unmanned Aerial Vehicles (UAVs) are useful in the estimation of LAI through the generation of a 3D grapevine mass surface model (KALISPERAKIS, I. et al. 2015). Calibration resulted in a correlation of $R^{2}=0.73$. Tractor-mounted LiDAR was used for LAI determination in the vineyards of Catalonia (ARNó, J. et al. 2012).

In Hungary we could not find any publication on the estimation of LAI, but GreenSeeker 505 vegetation sensors were applied in the wine region of Tokaj-Hegyalja combined with Normalized Differential Vegetation Index (NDVI) and relationships between grapevine growth and soil water budget were pointed out (Riczu, P. et al. 2018).

For the continuous monitoring of crop growth remote sensing techniques are of increasing significance. The application of UAVs and hyperspectral cameras placed at low heights opened a new chapter in the investigation canopy biomass in vineyards (ARNó, J. et al. 2012; BADr, G. et al. 2015; KALISPERAKIS, I. et al. 2015). The closer the sensors are set to vinestocks, the more precise detection can be expected (Towers, P.C. et al. 2019). The techniques of image processing have kept pace with the image capturing technology. There is an equal focus on both vegetative growth and berry ripening (Whalley, J. and Shanmuganathan, S. 2013). Studying daily evapotranspiration of vine, Semmens, K.A. et al. (2016) found that hyperspectral techniques can support water management strate- gies. Automatic detection of pests, for instance, of Flavescence dorée, proved to be successful (Al-SAdDik, H. et al. 2019). The application of the SPA Successive Projection algorithm ensures more than 96 per cent accuracy in pest detection. RGB (red, green and blue images superimposed), multispectral and thermal imagery is widely employed to assess vineyard variability and to monitor the evolution of grapevine parameters to support precision viticulture and decision making (PÁDUA, L. et al. 2020). RGB images taken by UAV were used to estimate canopy mass and LAI in Texas (Mathews, A.J. and Jensen, J.L.R. 2013) and in Savoy (СомвA, L. et al. 2019), where a correlation of $R^{2}=0.82$ was attained.

Our experiments take place in an organic vineyard of the Villány Wine District. Organic viticulture is rapidly spreading worldwide because it offers multiple advantages over conventional cultivation (Рвовsт, B. et al. 2008; Provost, C. and Pedneault, K. 2016), producing high quality grapes and wines with lower inputs, conserving biodiversity and keeping pests and diseases at low levels. In organic viticulture only organic fertilizers and non-synthetic pesticides are allowed and soil disturbance is reduced by minimum tillage and grassing (Meissner, G. et al. 2019). Biodynamic viticulture, where specific preparates are applied to enhance bacterial action, is also popular in many countries (Meissner, G. et al. 2019). In southern France conversion to organic viticulture was found to significantly increase bulk density, total organic carbon content (TOC) and cation exchange capacity (CEC) of soils (CoLL, P. et al. 2011). These findings point to higher soil quality. In the experiments microbiological benefits were also remarkable: much higher microbial biomass carbon, nematode and omnivore, plant-feeder and fungal densities were found in organic plots. After an initial decrease in nutrient $(\mathrm{N}, \mathrm{P}, \mathrm{K})$ contents, values began to rise when microbial life established itself and released organic acids. The earthworm populations, however, did not show increases (probably explained by more soil compaction) (Coll, P. et al. 2011). 
Soil erosion in vineyards with steep slopes depletes soil fertility and indirectly reduces the quality of grapes and wine (Rodrigo-Comino, J. et al. 2018). A large variety of soil conservation measures are proposed (from minimum tillage to mulching and even geotextiles Kertész, Á. et al. 2007). Their successful application, however, is heavily dependent on local conditions. Numerous papers deal with the advantages of organic farming with respect to soil erosion (see e.g. Kirchoff, M. et al. 2017).

Along with its benefits, organic viticulture has to face numerous challenges not only in cultivation and nutrient supply but also in plant protection. Excluding synthetic pesticides from among the alternatives of plant protection can lead to higher incidence of downy and powdery mildew and yield loss. In organic farming, $\mathrm{Cu}$ is approved and commonly applied for downy mildew caused by the fungus Plasmopara viticola (DöRING, J. et al. 2015) but it leads to a hazardous extent of $\mathrm{Cu}$ accumulation in soils. Weed control is another topic where organic viticulture needs innovations (BAumgartner, K. et al. 2009; BeKkers, T. 2011). In California mechanical weed management was found most effective and economical, without affecting grape yield or quality (ShresthA, A. et al. 2013). In contrast, in the vineyard studied in the present project cover cropping is the primary means of plant protection supplemented with the application of $\mathrm{Cu}$ compounds, biostimulants enhancing induced resistance and feromon dispensers (Steenwerth, K.L. and Belina, K.M. 2008; Werner, J. and Forgács, B. 2016).

Related to the issues mentioned in the Introduction, the main questions to be answered by the present research were the following:

- How does biomass production change in the various phenological phases of grapevine development? This can be revealed by phenometric investigations.

- How the values of Leaf Area Index (LAI) reflect these changes over the growing season? To answer this question field monitoring and calculations were necessary.

- What is the medium-term impact of the above trends on carbon sequestration? To this end, laboratory analyses of canopy, biomass, different properties of soil and eroded sediment were performed.

- How much organic matter is lost by soil erosion from the bare alleys between vinestock rows? The amounts were estimated by field monitoring and laboratory analyses of soil sediment samples.

\section{Study area}

The study area lies in the Pannonian pedoclimatic region, in the Villány Wine District, Baranya County, Southwest Hungary (coordinates: $45^{\circ} 51^{\prime} 47.8^{\prime \prime} \mathrm{N}, 18^{\circ} 26^{\prime} 39.6^{\prime \prime} \mathrm{W}$ - Figure 1). Mean annual temperature is $10.7{ }^{\circ} \mathrm{C}$ (1981-2010) average annual precipitation is $680 \mathrm{~mm}$, annual potential evapotranspiration is $650 \mathrm{~mm}$ (1981-2010). Maximum monthly rainfall was $186.8 \mathrm{~mm}$ (May 2010), while maximum daily rainfall was low in comparison with other regions: $53.2 \mathrm{~mm}$ (on 23 April 1942 - Hungarian Meteorological Service, OMSz). Most recently in June 2009, heavy hail affected 400 ha of vineyard area and created run-off carved gullies of 50-70 cm depth.

The plantation has been cultivated for several centuries on southern slopes of $15-20^{\circ}$ inclination with loamy, slightly calcareous and compacted Ramann's brown forest soil, in the World Reference Base system (IUSS Working Group WRB 2015: Chromic Cambisol). At the experimental plot soil depth is $1.7-2.0 \mathrm{~m}$. Average humus content in the topsoil (uppermost $30 \mathrm{~cm}$ ) is 3.36 per cent (with standard deviation of $r=0.36)$, total carbon content $\left(\mathrm{C}_{\text {total }}\right)$ is $25.96 \mathrm{~g} \mathrm{~kg}^{-1}, \mathrm{C} / \mathrm{N}$ ratio is 17.13 . In soils $\mathrm{N}$ mineralization is well balanced. Susceptibility to water erosion is high on the hillslopes.

The Gere Attila Winery has vine plantations of 70 ha, out of which the Diverfarming experiment covers 1.36 ha. Apellation wine is produced in the premium vineyards of Kopár, Feketehegy, Ördögárok (Teufelsgraben) and Csillagvölgy (Sterntal). The main red grape varieties grown over 75 per cent of land are Cabernet Franc, Cabernet Sauvignon, Merlot and Portugieser. Guyot training (cane prun- 

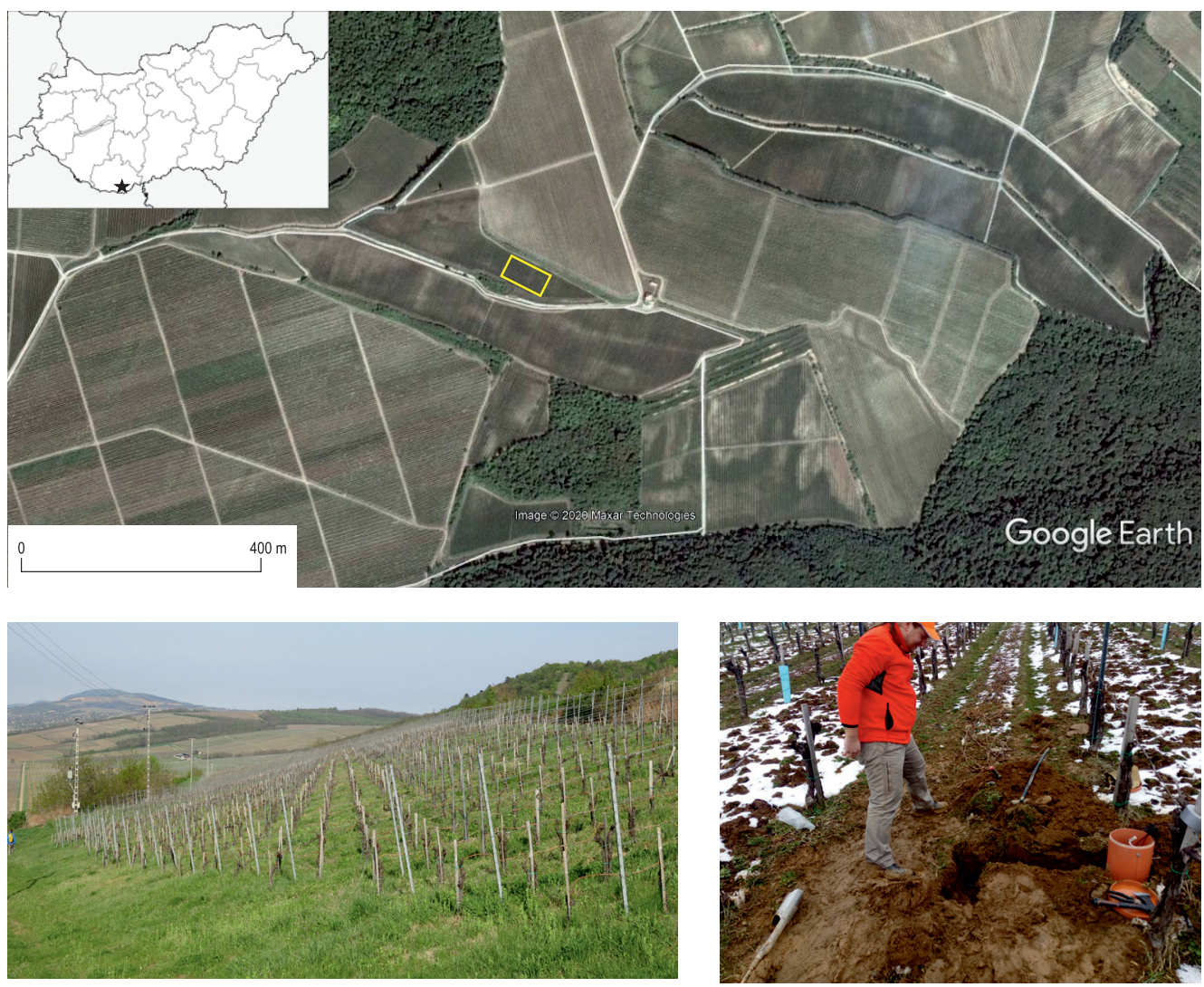

Fig. 1. Location of the study area: Konkoly vineyard, Villány Wine District, Baranya County, Southwest Hungary (Base map: GoogleEarth, photos by Dezső, J.)

ing - Puckette, M. 2016) is predominant with a planting density of 2.3 times 0.6 stocks $(7,200$ stocks ha-1) (WERner, J. and Forgács, B. 2016). Organic viticulture was extended from 11 ha in 2009 to the entire vineyard area in 2019. Bud density is reduced to $2-4$ buds $\mathrm{m}^{-2}$ to regulate yield. Most of the vineyards are of mature age, the oldest was established in 1992.

Vinestock interrows/alleys are sown with a mixture of grass and leguminous herbs at five- or six-year intervals. The species composition of cover crops is altering spontaneously. Interrows are mown on four or five occasions during the growing season. Hay is left on the ground to slowly decompose and add to soil organic matter. As a control treatment vineyard plots without interrow vegetation are instrumented.

\section{Methods}

\section{Image capture, processing and analysis}

To obtain reliable data on crop growth, remote sensing should take place as close to the vinestocks as possible (Towers, P.C. et al. 2019). Covering extensive areas simultaneously, the application of Unmanned Aerial Vehicles (UAVs) for imaging is an option, but day-to-day monitoring using UAV is difficult to implement. If a camera fixed on a pole is 
used, upscaling to areas of several hectares is corrected by supplementary calibration. With the above considerations in mind, to follow the growth of both grape plant and intercrops (the extent of their surface coverage) cameras were placed on high poles (Photo 1).

The principal criteria the images had to meet were the following:

- Individual leaves had to be well detectable in the image;

- The cameras had to be able of both night (infrared) and day imaging;

- The distances between posts and cordon wires could be used as reference points in image interpretation.

The selected equipment was a DÖRR SnapShot Multi Mobil 3G 16MP HD camouflage camera, usually applied as a low-angle $\left(58^{\circ}\right)$ wild camera. Supplied with 60 LED lights of $940 \mathrm{~nm}$ wavelength, it is also suitable for night imaging. Images were taken at 30-min intervals and forwarded to the server of the Faculty of Sciences, University of Pécs. Two cameras were placed on a 6-m high pole serving multiple purposes: observations of biomass growth, cultivation interventions in interrows and traces of erosion at the end of rows (Photo 1). Each image covers six full vinestocks.

The growth of individual leaves and the canopy was reconstructed from the images using Image $1.52 \mathrm{~S}$ software. Image processing aimed at expressing percentage growth relative to the portrayed area. Unfortunately, because of the changeable illumination, this task could not be fully automated (as described by Fuentes, S. et al. 2014). Careful manual processing was employed to avoid false interpretation. A crucial step is the setting of colour threshold level with the Li algorithm (LI, C.H. and TAM, P.K.S. 1998) to allow marked distinctions in the colour image (TалімA, R. and Kato, Y. 2011). A colour composite of the grape leaf was selected. If the colour of the leaf of the cover crop is too similar to that of the grape, the error increases. Therefore, images taken in the morning were preferred for the segmentation (Figure 2).

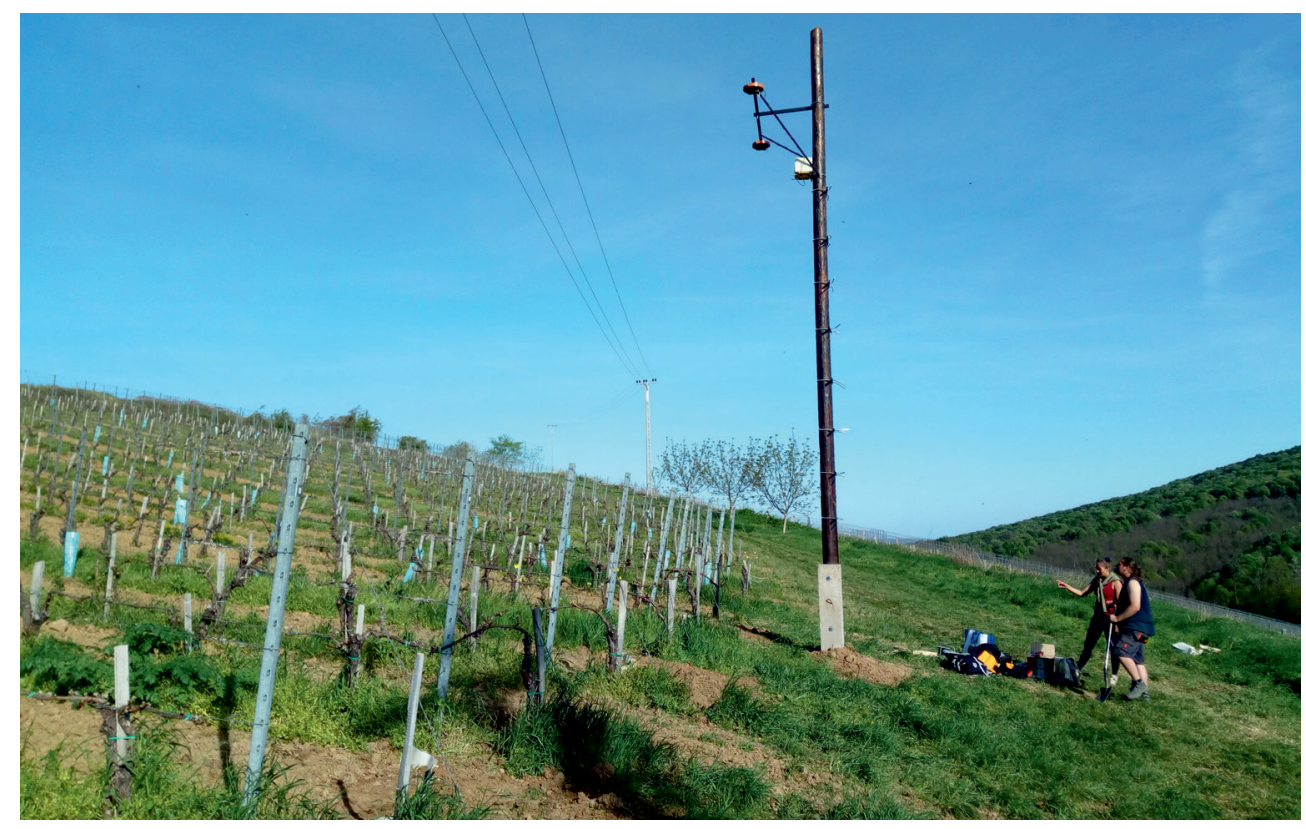

Photo 1. The monitoring system for crop growth (Photo by Dezsó, J.) 

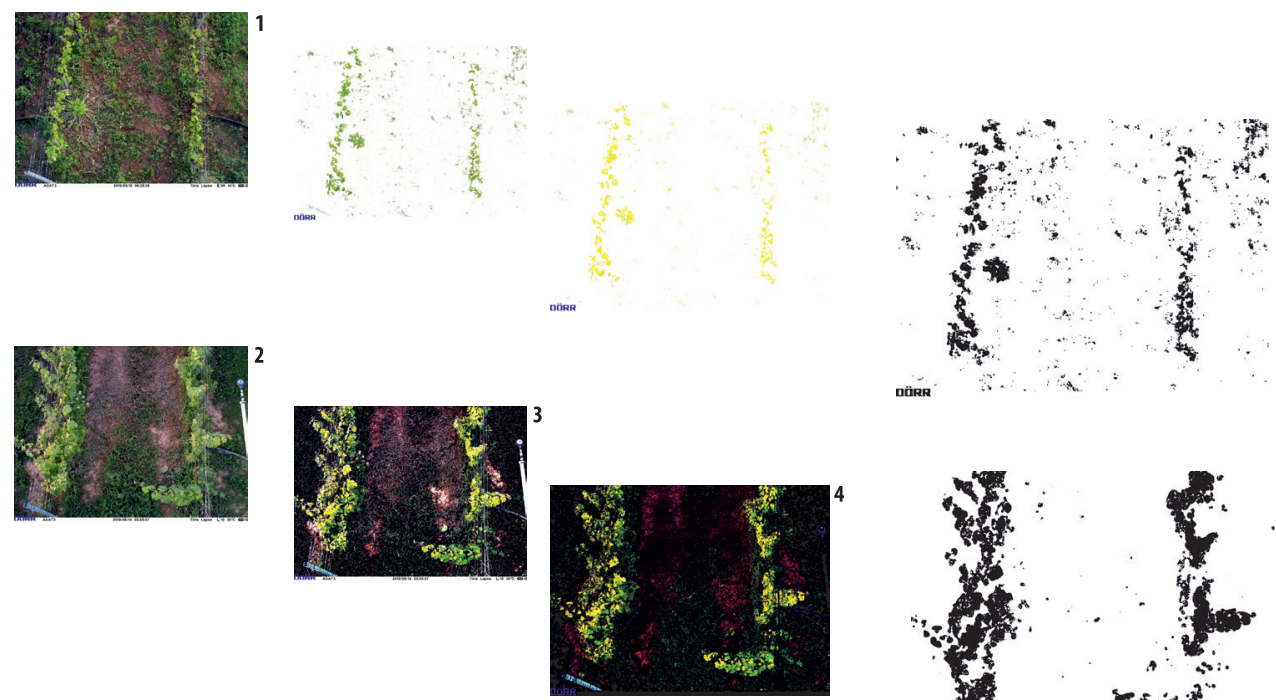

Fig. 2. Steps in fragmentation (by Dezsô, J). 1 = conversion of the image to scale; 2 = colour enhancement; 3 = setting colour threshold: white background, HSB or RGB colour code, using Li or MaxEnthropy method; 4 = processing the binary image: filling holes, skeletonizing, despeckling, dilating or eroding image

The binary image was converted to scale, i.e. the number of pixels was counted on $1 \mathrm{~cm}$ distance, and, accordingly, the software computed leaf area.

\section{Estimation of leaf area growth}

The value of momentary leaf area per hectare land was calculated from the equation:

$$
A=T \cdot H \cdot H L \cdot A L,
$$

where $A$ is leaf area per hectare $\left(\mathrm{m}^{2} \mathrm{ha}^{-1}\right)$; $T$ is vinestock density (number ha-1); $H$ is shoot density, shoots per stock (number); $H L$ is leaf density, leaves per shoot (number); $A L$ is area of individual leaves $\left(\mathrm{m}^{2}\right)$.

The data on the dynamics of leaf area and biomass growth are converted into dry mass per hectare using the equation:

$$
A=I_{B I N} \cdot L L_{A} \cdot F,
$$

where $A$ is leaf area per hectare $\left(\mathrm{m}^{2} \mathrm{ha}^{-1}\right) ; I_{B I N}$ is grape leaf area measured in the binary im- age (\%); $L L_{A}$ is total leaf area in the vertical leaf storeys $\left(\mathrm{m}^{2}\right) ; F$ is multiplying factor to extend data over 1 ha area (-).

In order to establish the $\mathrm{LL}_{\mathrm{A}}$ value, a statistical survey of leaf amount per vinestock was performed under fully developed conditions at 27 sites of the experimental area and expressed both as area and dry mass. Assuming a uniform growth rate of leaves, the F multiplying factor was regarded constant.

In summary, the leaf areas segmented from the individual images were extended to 1 ha vineyard area using data from the survey of leaf areas of vinestocks. The standard deviations of input data ranged from 20 to 30 per cent (occasionally reaching 40\%). Leaf biomass can be calculated from the mass of dry leaves (expressed in $\mathrm{kg} \mathrm{ha}^{-1}$ or tha-1).

\section{$\mathrm{C} / \mathrm{N}$ ratio in biomass and soil}

$\mathrm{C} / \mathrm{N}$ ratio is calculated for the grapevine and intercrops (roots and stalks). C and $\mathrm{N}$ contents 
are established at high temperature in oxygen-rich environment using the Dumas technique elaborated in 1831 (OIV 2009; AgüERA Buendía, E. and de la Haba Hermida, P. 2019). The measurements are carried out by a LECO CHN628 elementar analyzer. Carbon is determined by non-dispersive infrared absorption and nitrogen by a Thermal Conductivity (TC) Cell at the Department of Environmental Systems Science, ETH, Zurich. Well-homogenized samples are heated to over $1,000{ }^{\circ} \mathrm{C}$ in a high-temperature furnace where the combustion takes place rapidly in the presence of pure oxygen. Nitrogen oxides are converted into molecular nitrogen, combustion products were removed by helium gas and then nitrogen gas was obtained when conducted through hot copper. Absorbent traps are used to remove water and only $\mathrm{N}_{2}$ and $\mathrm{CO}_{2}$ are left behind. Total nitrogen content is measured by a thermal conductivity detector.

Organic carbon in the soil and sediments was determinated by wet combustion $\left(\mathrm{OC}_{\mathrm{wc}}\right)$, using the Tyurin method (Jankauskas, B. et al. 2006). The dried samples were mixed with potassium chromate and extracted by concentrated sulphuric acid. The decanted and filtered liquid was measured by photometric method at $485 \mathrm{~nm}$ wavelength.

The same protocol was applied for soil samples. To obtain total organic carbon (TOC), the major energy source of microbial life in soils, a five-hour treatment with 10 per cent hydrochloric acid was used.

Instead of the Dumas combustion method (CAmbardella, C.A. and Elliot, E.T. 1992), the standard humus determination method based on $\mathrm{OC}_{\mathrm{wc}}$ measurement is widely used in Hungary. In the Diverfarming project in situ parallel soil investigations include the determination of total carbon $\left(C_{\text {total }}\right)$, TOC and calculated total inorganic carbon (TIC).

\section{Nitrogen forms in soils}

Soil mineral $\mathrm{N}$-forms (nitrate, nitrite and ammonia) represent the pool of nitrogen available to the crop and determined by the very sensitive and specific Griess-Ilosvay method (Keeney, D.R. and Nelson, D.W. 1982) using Nanocolor 500D VIS photometer (MachereyNagel Gmbh, Düren, Germany). After treatment with potassium-chloride and homogenization, the soil samples (taken from $10 \mathrm{~cm}$ and $30 \mathrm{~cm}$ depths) are centrifuged at 3,000 rotations per min for $10 \mathrm{~min}$ and $\mathrm{KCl}$ is decanted. Nitrite ions react with sulfanilic acid and 1-naftil-amin solution and induce red azo-dye formation. Both $\mathrm{N}$-forms are measured at $520 \mathrm{~nm}$ in the spectrophotometer.

\section{Soil carbonate}

Topsoil carbonate contents (calculated $\mathrm{C}_{\text {carb }}$ ) were determined by Scheibler calcimeter using 10 per cent hydrochloric acid. The carbonate forms are released and $\mathrm{CO}_{2}$ is generated. The amount of the developed $\mathrm{CO}_{2}$ is converted to $\mathrm{CaCO}_{3}$.

\section{Particle size measurement}

Particle size distributions of topsoil samples were determined via a static light scattering technique using a Malvern Mastersizer 3000 Hydro LV (Malvern Inc., Malvern, United Kingdom) particle size analyser at the Szentágothai Research Centre, University of Pécs. During sample preparation OM was removed by $\mathrm{H}_{2} \mathrm{O}_{2}$ and shell fragments by 20 per cent $\mathrm{HCl}$. The wet dispersion method allowed for a detailed measurement of grain sizes from $0.01 \mu \mathrm{m}$ to $2,100 \mu \mathrm{m}$.

\section{Greenhouse gas flux measurements}

Soil fluxes of greenhouse gases have been monitored in 2018-2019, employing 51 sampling events typically 1-3 hours before local noon. This protocol was approved following preliminary investigations in 2018. The method is described in ReginA, K. and HüpPI, R. (2019). Altogether 18 pieces of non-transparent static chambers of $25 \mathrm{~cm}$ diameter and 
$5 \mathrm{~cm}$ height (of own design) were arranged evenly among rows and interrows. Samples were taken by a syringe into evacuated vials of $20 \mathrm{ml}$ at $\mathrm{t}=0,10,20,30$ minutes from the closure of the chambers for gas chromatographic analysis. Fluxes of methane, carbon dioxide and nitrous oxide were calculated from the accumulation rate of concentrations in the chamber during the sampling.

\section{Erosion measurements}

In our case Gerlach troughs (GerLACH, T. 1967) could not be applied without soil disturbance during installation (KINNELL, P.I.A. 2016). Neither did the width of alleys between vine rows and slope length favour Gerlach troughs. Twelve sediment traps (three in bare interrows and three times three in the interrrows with cover crops) designed specially for the vineyard were placed at the end of vine rows in the experimental plot (Photo 2). The eroded sediment was collected in 30-litre barrels. Vertically set flexible rubber bands were used to retain sediment and not to disturb mechanized vine cultivation.

\section{Results and discussion}

\section{Parametrization of biomass growth}

The estimation of biomass growth is based on the growth of grape leaves and shoots and the development of the intercrop modified by the removed biomass of berries.

\section{Phytotechnological interventions}

Both generative and vegetative productions are controlled by bud load and its distribution regulated by pruning. The guyot canopy shape

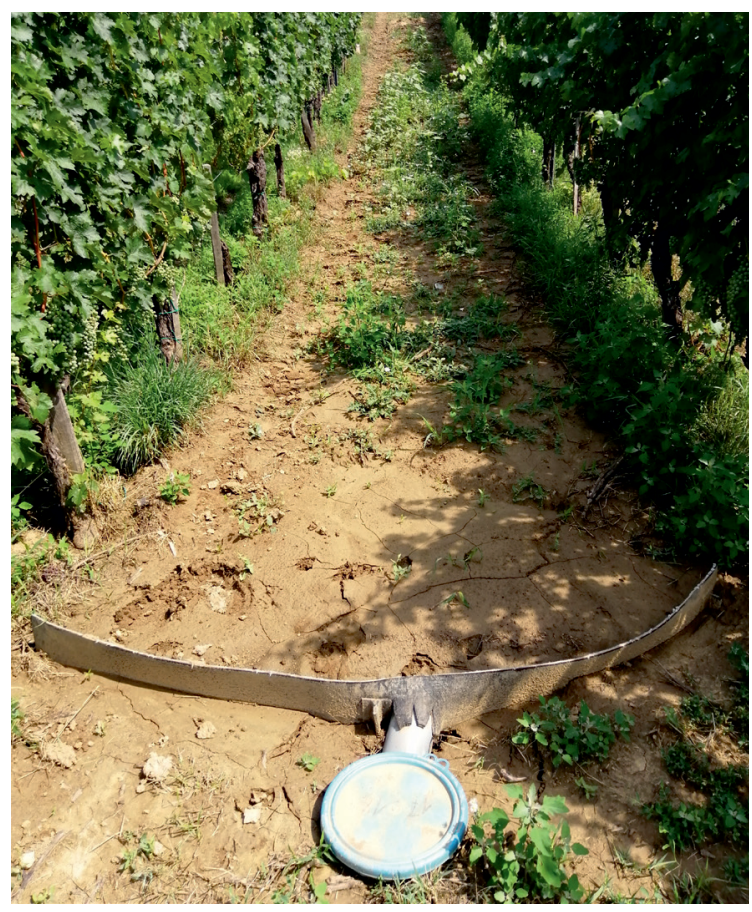

Photo 2. Sediment trap with eroded material on 26 May 2018 (Photo by Dezsó, J.) 
(Puckette, M. 2016), applied in the study area, is characterized by a narrow, fan-like, photosynthetically active profile (Photo 3 ). In regulated plantations the canopy serves intensive growth. Bud burst usually occurs in early April and the camera could detect the first buds in the second half of April. By that time, the nutrients necessary for shoot growth have been already stored in the vinestock. Intensive shoot growth ends in mid-June when shoots reach the height of the uppermost wire (at $160 \mathrm{~cm}$ ). From bud burst on, over the first half of the leaf growth period, leaves require more assimilated matter than they are able to produce.

At the beginning of bloom leaf thinning induces the increase of total leaf area. On each shoot 10-15 leaves are desirable. Thinning shoots (to 6-7 shoots per stock) in early May can also regulate the number of clusters and leaf area. Cutting shoots short can induce vegetative growth from the end of June to late August. Mechanized vine 'hedging', i.e. pruning off the over-hanging currentseason growth at veraison, was applied at $2 \mathrm{~m}$ height and removed ca 15 per cent of the vine biomass. Self-shading should be avoided through reducing the canopy wall to $2 \mathrm{~m}$. In the phase of ripening bunch spacing is applied in premium vineyards to prevent vegetative (2-4 $\mathrm{m}^{2} \mathrm{~kg}^{-1}$ leaf area per yield) and generative (0.5-1.5 $\mathrm{m}^{2} \mathrm{~kg}^{-1}$ leaf area per yield) overload (Figure 3).

In the Konkoly vineyard eight phytotechnological interventions are performed to achieve these goals. Pruning follows in winter, when the cut-off vine shoots have a lower moisture content (10-15\%). Dry matter adds up to $0.42-0.57 \mathrm{~kg}$ per stock (on the average: $0.48 \mathrm{~kg}$ ), i.e. $3,657 \mathrm{~kg} \mathrm{ha}^{-1}$ in a year. The C/N ratio of shoots ranges from 90 to 1 and 100 to 1 (Kostov, O. et al. 1996).

Phytotechnological interventions also include intercropping. Intercrops are mown 4 or 5 times

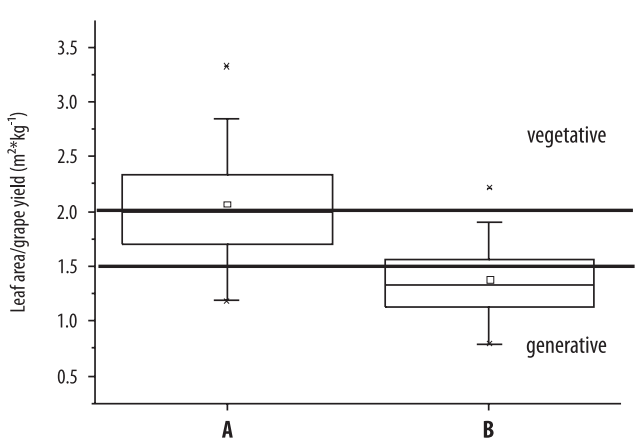

Fig. 3. Leaf area/yield ratio for $0.8 \mathrm{~kg}$ yield per stock (A) and for $1.2 \mathrm{~kg}$ yield per stock (B)

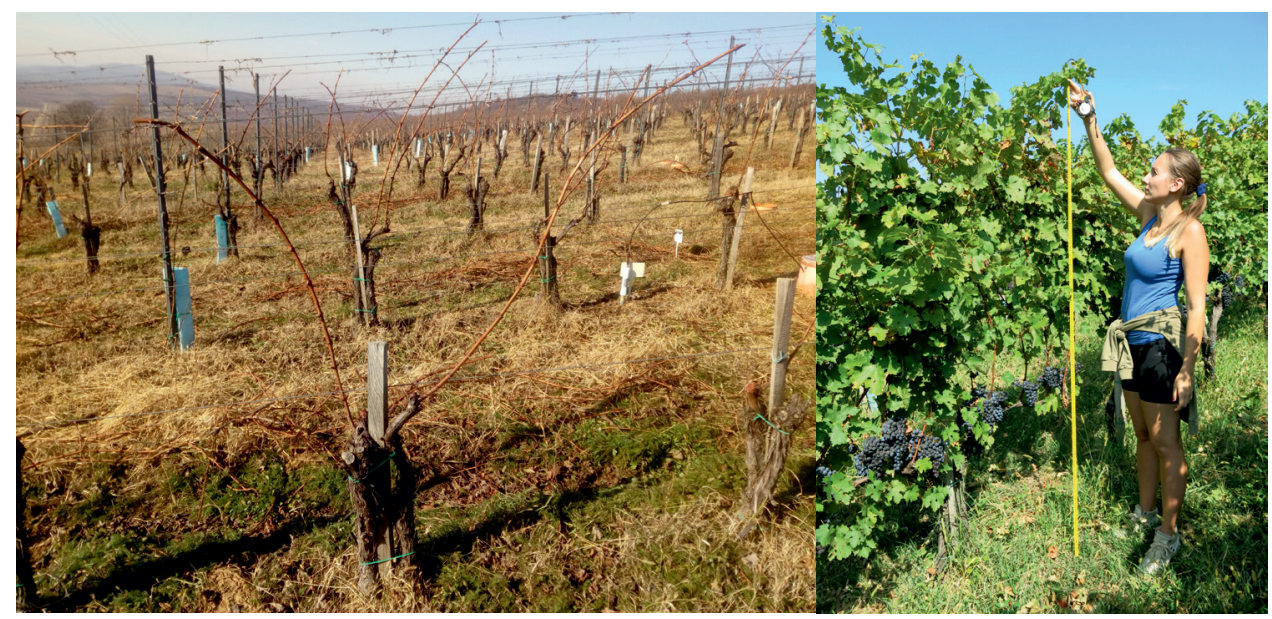

Photo 3. Vinestocks after pruning (left) and during harvest (right) (Photos by Dezső, J.) 
a year and this provide $823 \mathrm{~kg} \mathrm{ha}^{-1}$ dry mass. The $\mathrm{C} / \mathrm{N}$ ratio of the root zone is 28.19 and of the above-ground parts is 17.88 (Figure 4).

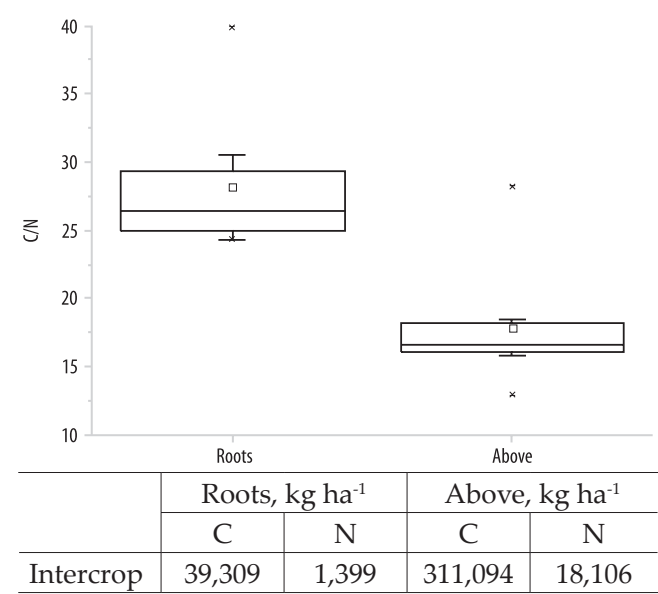

Fig. 4. $\mathrm{C} / \mathrm{N}$ ratios of roots and above-ground biomass, and average $\mathrm{C}$ and $\mathrm{N}$ contents of the wet mass of shoots (for $\mathrm{m}=3,657 \mathrm{~kg} \mathrm{ha}^{-1}$ )

In the Konkoly vineyard sustaining manuring (30-40 $\mathrm{t} \mathrm{ha}^{-1}$ ) takes place in every fourth or fifth year. This involves the replenishment of 200-300 kg N (KáDÁr, I. 1997). Cultivation measures aim at forming 6-7 shoots per stock (of $1.38 \mathrm{~m}^{2}$ area), 14-22 leaves per shoot and $0.8-1.2 \mathrm{~kg}$ yield per stock. Calculating with median values LAI is estimated at 1.156.

\section{Average leaf area}

At full canopy development, in September, 90 leaves were collected to count leaf area using the photometric method and the ImageJ software (Figure 5). The results were evaluated and represented by Origin 8.5 and PAST3 statistical programmes.

Estimated leaf area per hectare (calculated from Equation 2) was plotted against the critial period of growth (from 27 April). The dynamics of growth are closely correlated $\left(\mathrm{R}^{2}=0.99\right)$ to the Richards' trend function (Figure 6):

$$
\hat{y}_{t}=\frac{K}{\left(1+v e^{-c(t-m)}\right)^{1 / v}}
$$

where $\hat{y}_{t}$ is the Richards' trend; $K$ is the level of the saturation; $t$ is the vicarial value; $v(v>$ 0 ) influences the value of the inflexion point; $c$ $(c>0)$ influences the function value; $m(m>0)$ is the date of maximum growth.

In the case of the experimental area the parameter values are the following: $v=0.41$ (unitless); $c=0.21 ; m=25$ (day) and $K$ is $8,493 \mathrm{~m}^{2}$ leaf area/ha on the $60^{\text {th }}$ day

\section{Leaf storeys and cluster thinning}

The number of leaf storeys along with the corresponding leaf amount were measured at 27 sites for each vinestock. Above the upper
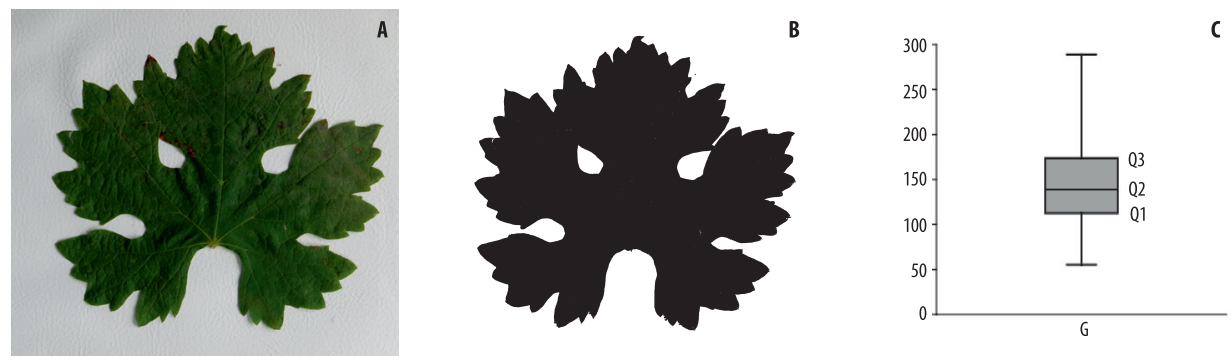

Fig. 5. Determination of leaf area. $a=$ original image, $b=$ binary image, $c=$ results in box diagram, where $Q_{1}=112.88$; $\mathrm{Q}_{2}=138.78 ; \mathrm{Q}_{3}=172.07 \mathrm{~cm}$ 


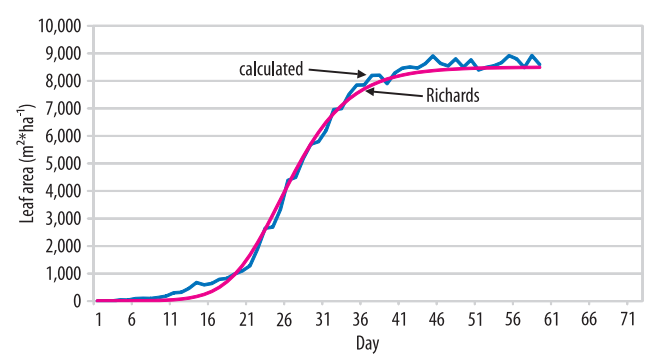

Fig. 6. Estimated growth of leaf area per hectare over 60 days (from 27 April 2019 to 27 June 2019) (blue, based on image analysis and calculations) compared to the Richards' trend function (RIchards, F.J. 1959) (purple)

cluster level 10-12 leaf storeys and $0.18 \mathrm{~m}^{2}$ leaf area per stock are optimal. The estimation of biomass production also relies on cluster thinning. 10-50 per cent of clusters are removed to reduce yield and increase average cluster mass. Lower clusters have higher sugar and lower acid contents. In premium vineyards not more than $1.2 \mathrm{~kg}$ yield per stock (or $8.5 \mathrm{t}$ $\mathrm{ha}^{-1}$ ) is permitted. In the experimental plot this value is usually $0.8 \mathrm{~kg}$ per stock. Matтhiasson, S. (2013) claims that in cooler regions if half of the berries are removed, sugar content can rise by 10-20 per cent and alcohol content potentially by 11-13 per cent, which makes a great difference in wine style. Similar observations are made in Hungarian vinicultural literature (see ЈАКАB, G. et al. 2013). been selected from the distribution of leaf area. The most common parameter value was taken into account.

\section{Soil carbon sequestration}

For the soil balanced $\mathrm{C} / \mathrm{N}$ ratios were observed. The difference between total $C$ and TOC is Total Inorganic C (TIC) (Figure 7). For $\mathrm{C}$ sequestration organic $\mathrm{C}$-forms are of the greatest importance. Therefore, along with the $\mathrm{C} / \mathrm{N}$ ratio, $\mathrm{C}_{\text {carb }} / \mathrm{N}$, TOC/N and TIC were also represented. Thus, Figure 7 shows the total specific $\mathrm{C}$ and $\mathrm{N}$ reserves in soil. Optimal soil $\mathrm{C} / \mathrm{N}$ ratio is $20-25$. Although to enhance carbon sequestration the amounts of organic C-forms has to be increased, the growth of $\mathrm{N}$ has to keep pace with that of $\mathrm{C}$. Higher $\mathrm{N}$ levels, however, are not desirable for the production of premium-quality grape and wine.

For soil $\mathrm{C}$ and $\mathrm{N}$ laboratory analyses showed the following values: $\mathrm{C}_{\text {total }}$ is $25 \mathrm{~g} \mathrm{~kg}^{-1}$, $\mathrm{N}_{\text {total }}$ is $1 \mathrm{~g} \mathrm{~kg}^{-1}$. Calculated for 1 ha this means $107 \mathrm{~kg} \mathrm{C}$ and $4.0 \mathrm{~kg} \mathrm{~N}$.

Since yields are rather strictly regulated, we calculated with average parameter values for minimum and maximum yields (Figure 8).

\section{Soil greenhouse gas fluxes}

Yearly mean of $\mathrm{CH}_{4}, \mathrm{CO}_{2}$ and $\mathrm{N}_{2} \mathrm{O}$ fluxes were estimated from the results of 51 sam-

Table 1. Input data for biomass estimation

\section{Leaf biomass}

The $\mathrm{C}$ and $\mathrm{N}$ contents of leaf biomass were determined in several steps (Table 1). Plant density, the number of shoots preserved and the leaves left on shoots were taken into account during calculations. Three quartile values have

\begin{tabular}{|c|c|c|c|}
\hline Parameter & \multicolumn{3}{|c|}{ Data } \\
\hline \multirow{2}{*}{ Number of vinestocks, pcs ha-1 } & \multirow{2}{*}{$\begin{array}{c}7,200 \\
\text { version } 1\end{array}$} & \multirow[b]{2}{*}{ version 2} & \multirow[b]{3}{*}{-} \\
\hline & & & \\
\hline Shoot, pcs stock ${ }^{-1}$ & $\begin{array}{c}6 \\
\min .\end{array}$ & $\begin{array}{c}7 \\
\text { average }\end{array}$ & \\
\hline Number of leaves, pcs stock ${ }^{-1}$ & $\begin{array}{c}14 \\
\left(Q_{1}\right)\end{array}$ & $\begin{array}{c}18 \\
\left(Q_{2}\right)\end{array}$ & $\begin{array}{l}22 \\
\left.Q_{3}\right)\end{array}$ \\
\hline Leaf area, $\mathrm{cm}^{2}$ & $\stackrel{112}{C}$ & $\begin{array}{l}138 \\
\mathrm{~N}\end{array}$ & $\begin{array}{l}172 \\
\mathrm{C} / \mathrm{N}\end{array}$ \\
\hline \multirow[t]{2}{*}{$\begin{array}{l}\text { Contents at blossom, \% (SD) } \\
\text { Contents at harvest, \% (SD) }\end{array}$} & $\begin{array}{l}43.65(0.62) \\
43.07(0.63)\end{array}$ & $\begin{array}{l}3.95(0.24) \\
1.92(0.25)\end{array}$ & $\begin{array}{l}11.11(0.59 \\
23.04(3.09)\end{array}$ \\
\hline & $\mathrm{C}$ & $\mathrm{N}$ & $\mathrm{C} / \mathrm{N}$ \\
\hline $\begin{array}{l}\text { Dry weight at blossom, } \mathrm{kg} \mathrm{ha}^{-1} \\
\text { Dry weight at harvest, } \mathrm{kg} \mathrm{ha}^{-1}\end{array}$ & $\begin{array}{l}417.73 \\
272.04\end{array}$ & $\begin{array}{l}47.80 \\
12.13\end{array}$ & $\begin{array}{l}- \\
-\end{array}$ \\
\hline
\end{tabular}




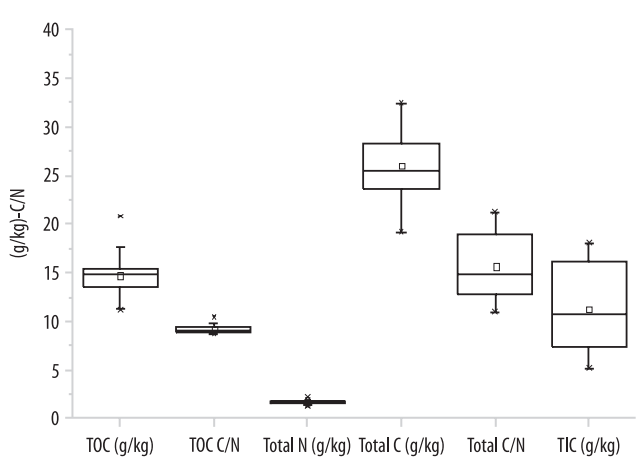

Fig. 7 TOC, TOC/N, total $\mathrm{N}$, total $\mathrm{C}$, total $\mathrm{C} / \mathrm{N}$ ratio and TIC in in situ soil samples

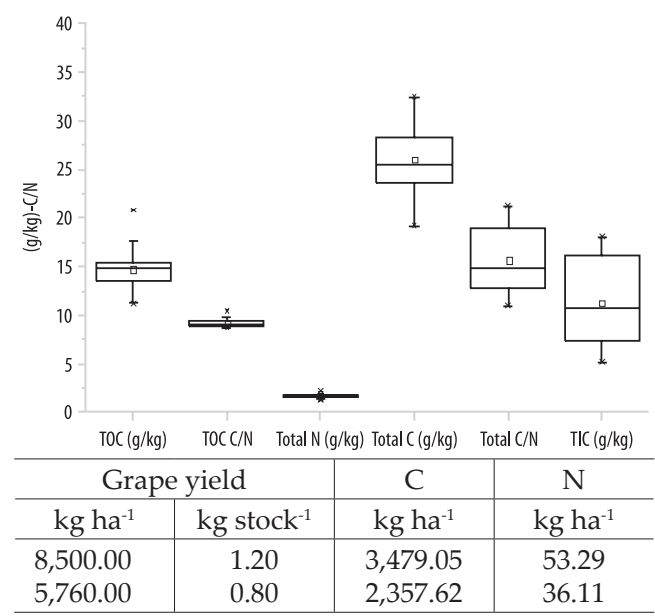

Fig. 8. $\mathrm{C} / \mathrm{N}$ ratio in grape yield (\%), and $\mathrm{C}$ and $\mathrm{N}$ amounts per hectare

plings and measurements (Figure 9). As fluxes were practically negligible below soil temperature of $5{ }^{\circ} \mathrm{C}$, sampling frequency was sparse during late fall, winter and early spring. The yearly mean fluxes were calculated taking into account the difference of sampling frequency between the cold and warm periods by weighting the data. Average emissions of carbon dioxide (by heterotrophic and autotrophic soil exhalation) and nitrous oxide were $2.83 \mathrm{tC} \mathrm{ha}^{-1} \mathrm{yr}^{-1}$ and $0.41 \mathrm{~kg} \mathrm{~N} \mathrm{ha}^{-1} \mathrm{yr}^{-1}$, respectively. Depending on anaerobic or aerobic conditions, soil was both a source or a sink of $\mathrm{CH}_{4}$ and the sign of fluxes changed accordingly, with an average deposition rate of $-0.81 \mathrm{C} \mathrm{ha}^{-1} \mathrm{yr}^{-1}$.

\section{Soil erosion on medium term}

Data on erosion require careful interpretation. Findings confirmed that the rate of erosion is higher in alleys than under vinestocks. In organic farming herbaceous (grass) cover crops are applied to reduce erosion. Erosion was more rapid in alleys which were ploughed for providing control plots within the frame of the Diverfarming project.

Soil erosion data are available for two years of experimentation. The rate of soil erosion from the area covered with grass mixture was $54 \mathrm{~kg} \mathrm{ha}^{-1} \mathrm{y}^{-1}$. The soil deposit had a high organic matter content (organic $\mathrm{C}$ up to ca $38 \mathrm{~g} \mathrm{~kg}^{-1}$ - Figure 10) as the lightest parts (fragmented plant remains) were washed down first. Total carbonate content was identical with that of in situ soil, but showed a wide range (see Figure 10). (It is a good opportunity to calculate enrichment ratio for the sediment.)

In the course of soil detachment the loamy topsoil is saturated and disintegrates and its grain size distribution becomes bimodal. The complicated process is influenced by cultivation and soil erodibility (Figure 11).

Intensive rainfall events are rather infrequent, only occur once in four or five years, when the corresponding soil removal could several fold exceed the values measured in the present experiment. In the summary table (Table 2) calculated values are extended to 5 years and also to 30 years, i.e. the approximate life cycle of the grapevine.

\section{Conclusions}

1. Camouflage cameras were successfully applied for crop growth monitoring. The process of image segmentation, however, could not be fully automated as the colour composition of the intercrops is highly variable. The discrepancy between real biomass growth 


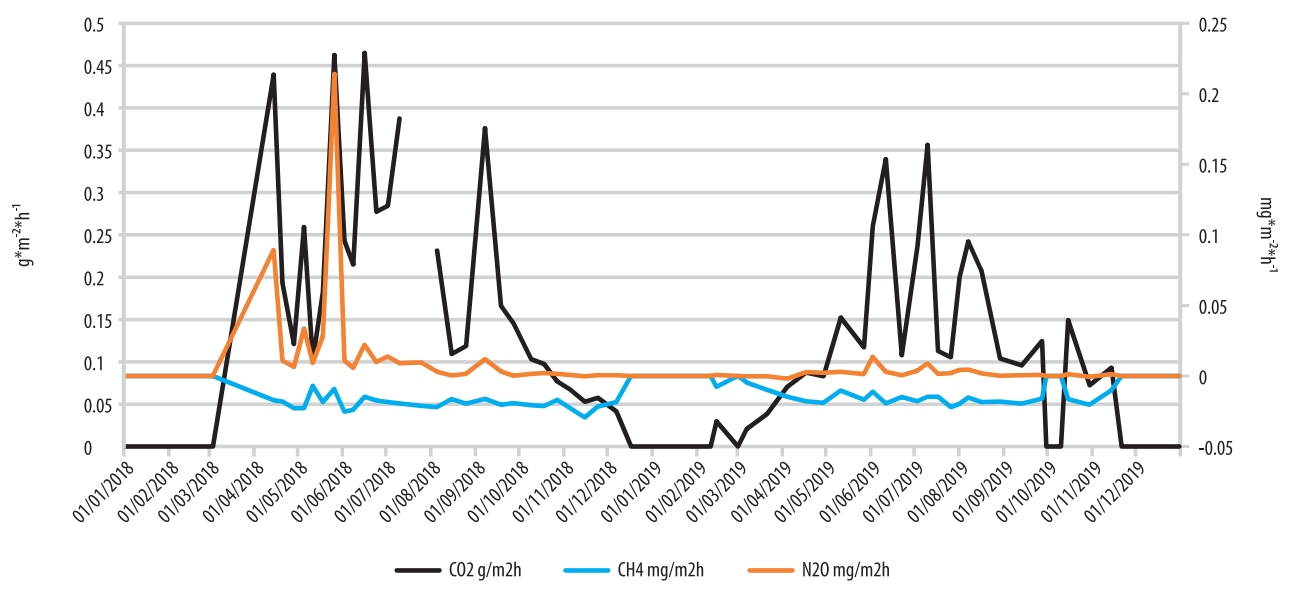

Fig. 9. Seasonal trend of soil fuxes of carbon dioxide $\left(\mathrm{g} \mathrm{m}^{-2} \mathrm{~h}^{-1}\right)$, methane and nitrous oxide $\left(\mathrm{mg} \mathrm{m}^{-2} \mathrm{~h}^{-1}\right)$ 2018-2019.

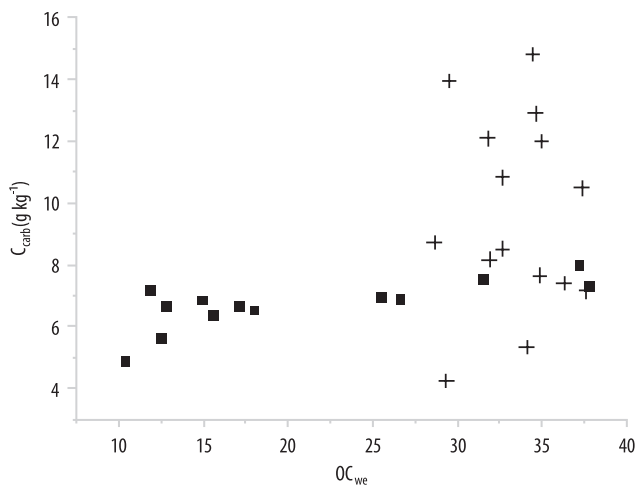

Fig. 10. Relationships between humus $\mathrm{C}\left(\mathrm{OC}_{\mathrm{we}}\right)$ and carbonate $\mathrm{C}\left(\mathrm{C}_{\text {carb }}\right)$ in in situ soil (+) and eroded soil deposit (•) (by Dezsô, J.)
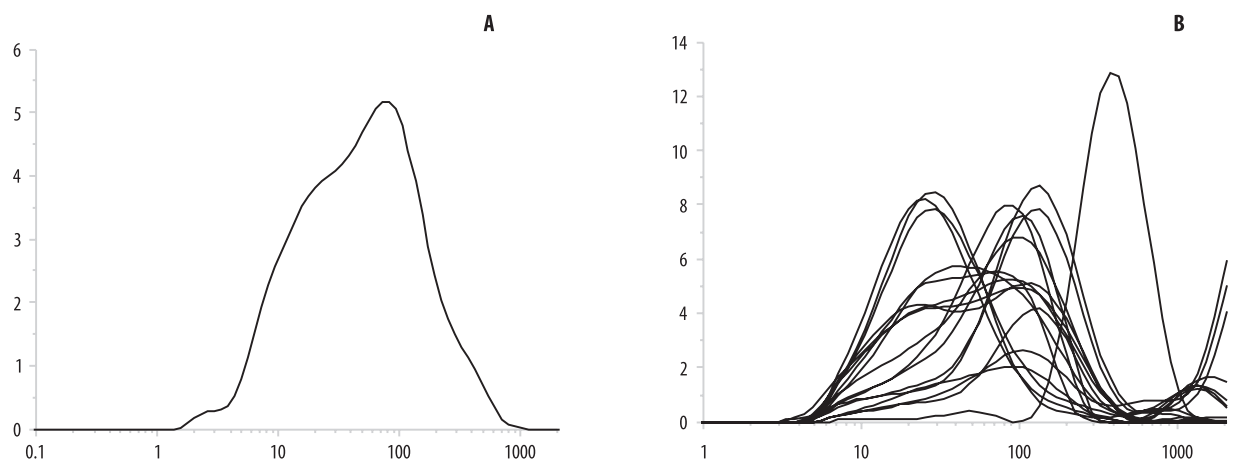

Fig. 11. Types of grain size distribution in the experimental: for in situ soil (a) and for soil deposits in traps (b) 


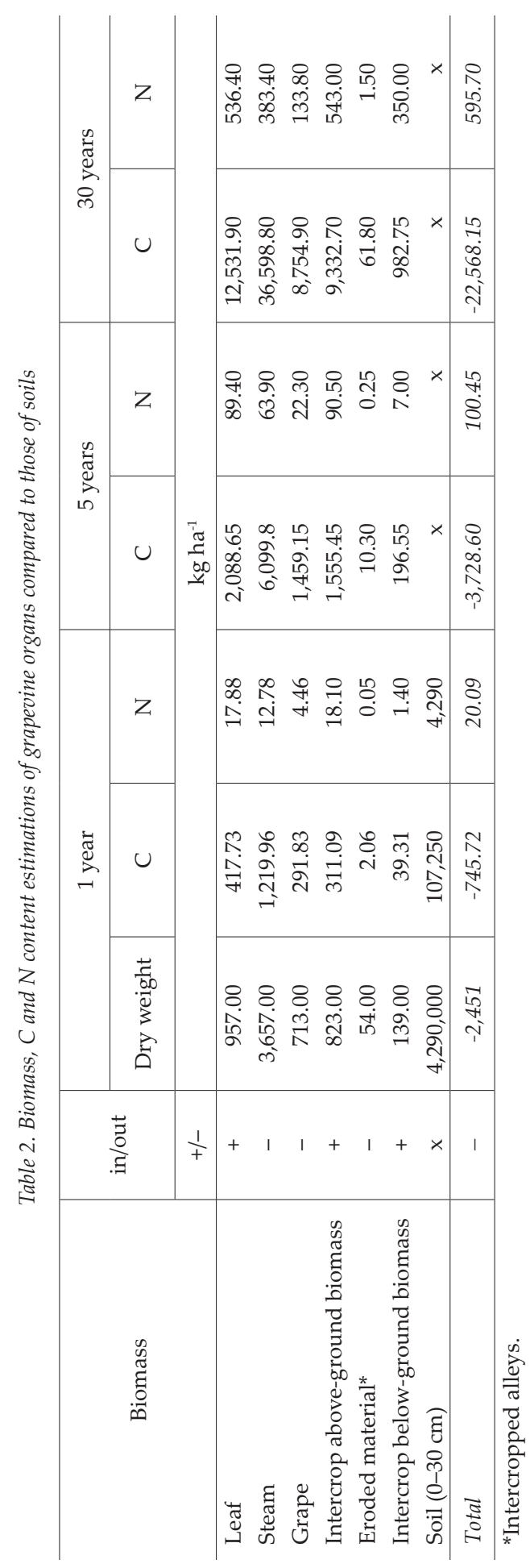

and the results of image analysis (error) can amount to 30-40 per cent. In the course of the growing season LAI changes respond to phytotechnological interventions. LAI estimation from counting collected leaves provided a normal statistical distribution. LAI and biomass growth can be modelled by the Richards' trend function (in accordance with ZEIDE, B. 1993). Biomass growth data were evaluated in comparison with net photosynthesis rates and soil greenhouse gas emissions.

2. The removal of cut shoots promotes the maintenance of optimal $\mathrm{C} / \mathrm{N}$ ratios (around 25 to 1 ) in the soil. On medium term, the removal or recycling of the biomass produced by pruning and hedging as well as the mowing of cover crops and fallen leaves significantly influence $\mathrm{C}$ and $\mathrm{N}$ recharge of the soil. Residual biomass could make part of the manure superfluous and this could improve the efficiency of low-input technologies on the long run.

Vineyards play an important part in C sequestration to mitigate global climate change. Any rise in soil $\mathrm{C}$ content, however, would require increased $\mathrm{N}$ reserves, but this is not desirable in quality wine production. The cut shoots of high $\mathrm{C} / \mathrm{N}$ ratio left on the ground would decompose slowly and upset the balance in the soil. In the future the boundary conditions of cultivation should be sought which satisfy the demands of quality grape and wine production parallel with reduced greenhouse gas emission and enhanced carbon sequestration in soils (JACKSON, D.I. and Lombard, P.B. 1993).

3. Soil and nutrient losses from the alleys by erosion are negligible on the short run. The grain size distribution of the eroded soil is bimodal and its TOC is one and a half fold higher than the original TOC. Total carbonate contents show a wide range.

Acknowledgements: Authors are grateful to the European Commission for the grant in the frame of the H2020 Diverfarming project (contract no 728003). 


\section{REFERENCES}

Agüera Buendía, E. and de la Haba Hermida, P. 2019. Carbon and nitrogen in leaves. In Handbook of Plant and Soil Analysis for Agricultural Systems. Eds.: Álvaro-Fuentes, J., Thiele-Bruhn, S., Lóczy, D. and Zornoza, R., Cartagena, RAI Universidad Politécnica de Cartagena (UPTC), 41-42.

Al-Saddik, H., Simon, J.C. and Cointault, F. 2019. Assessment of the optimal spectral bands for designing a sensor for vineyard disease detection: the case of 'Flavescence dorée'. Precision Agriculture 20.398-422. Doi: 10.1007/s11119-018-9594-1

Arnó, J., Del Moral, I., Escolà, A., Vallès, J.M., Calveras, J.L., Company, J., Masip, J., Sanz, R., Palacín, J. and Rosell-Polo, J.R. 2012. Mapping the Leaf Area Index in vineyard using a ground-based LiDAR scanner. Precision Agriculture 14. (3): 290-306. Doi: 10.1007/s11119-012-9295-0

Badr, G., Hoogenboom, G., Davenport, J. and SmithymAN, J. 2015. Estimating growing season length using vegetation indices based on remote sensing: A case study for vineyards in Washington State. Transactions of the ASABE 58. (3): 551-564. Doi: 10.13031/trans.58.10845

Baumgartner, K., Steenwerth, K. and Veilleux, L. 2009. Effects of organic and conventional practices on weed control in a perennial cropping system. Weed Science 55: 352-358. Doi: 10.1614/WS-06-171

BeKkers, T. 2011. Weed control options for commercial organic vineyards. Wine and Viticulture Journal 26. (4): 62-64.

Cambardella, C.A. and Elliot, E.T. 1992. Particulate soil organic-matter changes across a grassland cultivation sequence. Soil Science Society of America Journal 56. 777783. Doi: 10.2136/sssaj1992.03615995005600030017x

Castellarin, S.D, Matthews, M., Gaspero, G. and Gambetta, G. 2007. Water deficits accelerate ripening and induce changes in gene expression regulating flavonoid biosynthesis in grape berries. Planta 227. 101-112. Doi: 10.1007/s00425-007-0598-8

Celette, F., Gaudin, R. and Gary, C. 2008. Spatial and temporal changes to the water regime of Mediterranean vineyard due to the adoption of cover cropping. European Journal of Agronomy 29. 153-162. Doi: 10.1016/j.eja.2008.04.007

Coll, P., Le Cadre, E., Blanchart, E., Hinsinger, P. and Villenave, C. 2011. Organic viticulture and soil quality: A long-term study in Southern France. Applied Soil Ecology 50. 37-44. Doi: 10.1016/j.apsoil.2011.07.013

Comba, L., Biglia, A., Ricauda Aimonino, D., Tortia, C., Mania, E., Guidoni, S. and Gay, P. 2019. Leaf Area Index evaluation in vineyards using 3D point clouds from UAV imagery. Precision Agriculture 21. 1-16. Doi: 10.1007/s11119-019-09699-x

Creation Wines 2014. The art of winemaking: The vineyards. Hermanus, South Africa, CREATION.
Available at https://www.creationwines.com/2014/ art-winemaking-vineyards/

Delpuech, X. and Metay, A. 2018. Adapting cover crop soil coverage to soil depth to limit competition for water in a Mediterranean vineyard. European Journal of Agronomy 97. 60-69. Doi: 10.1016/j.eja.2018.04.013

Delrot, S., Medrano, H., Bavaresco, L., Or, E. and Grando, S. (eds.) 2010. Methodologies and Results in Grapevine Research. Dordrecht, The Netherlands, Springer Science and Business Media. Doi: 10.1007/978-90-481-9283-0

Döring, J., Frisch, M., TitTmann, S., Stoll, M. and Kauer, R. 2015. Growth, yield and fruit quality of grapevines under organic and biodynamic management. PloS ONE 10. (10): e0138445. Doi: 10.1371/ journal.pone. 0138445

EIP-AGRI 2020. Crop diversification and low-input farming across Europe: from practitioners' engagement and ecosystems services to increased revenues and value chain organisation. European Innovation Partnership for Agricultural productivity and Sustainability. Brussels, European Commission Publication. Available at https://ec.europa.eu/eip/agriculture/en/ find-connect/projects/diverfarming-crop-diversification-and-low-input

Fuentes, S., Poblete-Echeverría, C., Ortega-Farias, S., Tyerman, S. and De BeI, R. 2014. Automated estimation of leaf area index from grapevine canopies using cover photography, video and computational analysis methods. Australian Journal of Grape and Wine Research 20. (3): 465-473.

GERLACH, T. 1967. Hillslope troughs for measuring sediment movement. Révue Géomorphologie Dynamique 4. 1-173.

Greer, D.H. and Weston, C. 2010. Heat stress affects flowering, berry growth, sugar accumulation and photosynthesis of Vitis vinifera cv. Semillon grapevines grown in a controlled environment. Functional Plant Biology 37. (3): 206-214. Doi: 10.1071/FP09209

IUSS Working Group WRB 2015. World Reference Base for Soil Resources 2014, update 2015. International soil classification system for naming soils and creating legends for soil maps. World Soil Resources Reports No. 106. Rome, FAO.

JACKson, D.I. and LombARD, P.B. 1993. Environmental and management practices affecting grape composition and wine quality: A Review. American Journal of Enology and Viticulture 44. (4): 409-429.

Jakab, G., Csikászné, A.K., Hartman, B., Werner, J. and Kozma, P. 2013. Vineyards adaptation and varieties: The effect of varieties, clones and rootstocks on must sugar content. Alcohol level reduction in wine. Oenoviti International Network. Bordeaux, Institut des Sciences de la Vigne et du Vin. 9-13.

Jankauskas, B., Jankauskiene, G., Slepetiene, A., Fullen, M.A. and Boотн, C.A. 2006. International comparison of analytical methods of determining the soil organic matter content of Lithuanian 
Eutric Albeluvisols. Communications in Soil Science and Plant Analysis 37. 707-720. Doi: 10.1080/00103620600563499

KÁDÁr, I. 1997. A növénytáplálás alapelve és módszerei (Principles and methods of plant nutrition). Budapest, Research Institute of Soil Science and Agrochemistry, Hungarian Academy of Sciences. (in Hungarian)

Kalisperakis, I., Stentoumis, Ch., Grammatikopoulos. L. and Karantzalos, K. 2015. Leaf Area Index estimation in vineyards from UAV hyperspectral data, $2 D$ image mosaics and 3D canopy surface models. Photogrammetry, Remote Sensing and Spatial Information Sciences, Vol. XL-1/W4. International Conference on Unmanned Aerial Vehicles in Geomatics, 30 August - 2 September 2015, Toronto, Canada. Doi: 10.5194/isprsarchives-XL1-W4-299-2015

Keeney, D.R. and Nelson, D.W. 1982. Nitrogen Inorganic forms. In Methods of soil analysis. Part 2. $2^{\text {nd }}$ edition. Agronomic Monographs 9. Eds.: PAGE, A.L., Miller, R.H. and Keeney, D.R., Madison, WI, ASA and SSSA, 643-698.

Kertész, Á., Tóth, A., Szalai, Z., JaKab, G., Kozma, K., Воотн, C.A., Fullen, M.A. and Davies, K. 2007. Geotextile as a tool against soil erosion in vineyards and orchards. WIT Transactions on Ecology and the Environment 102. 1-9. Doi: 10.2495/SDP070592

KinnelL, P.I.A. 2016. A review of the design and operation of run-off and soil loss plots. CATENA 145. 257-265.

Kirchhoff, M., Rodrigo-Comino, J., Seeger, M. and RIES, J.B. 2017. Soil erosion in sloping vineyards under conventional and organic land use managements (Saar-Mosel Valley, Germany). Cuadernos de Investigación Geográfica 43. (1) 119-140.

Kostov, O., Tzvetkov, T., Petkova, G. and Lynch, J.M. 1996. Aerobic composting of plant wastes and their effect on the yield of ryegrass and tomatoes. Biology and Fertility of Soils 23. 20-25. Doi: 10.1007/ BF00335813

Kozma, P. 2001. A szőlő és termesztése II. A szőlő szaporítása és termesztéstechnológiája (Grape cultivation II. Grape propagation and cultivation technology). $3^{\text {rd }}$ edition. Budapest, Akadémiai Kiadó. (in Hungarian)

Kozma, P. 2002. A szólőés termesztése I. A szőlőtermesztés történeti, biológiai és ökológiai alapjai (Grapes and their cultivation I. Historical, biological and ecological bases of viticulture). $3^{\text {rd }}$ edition. Budapest, Akadémiai Kiadó. (in Hungarian)

Kuhn, N., Guan, L., Dai, Zh.W., Wu, B.H., Lauvergeat, V., Gomès, E., Li, S.H., Godoy, F., Arce-Johnson, P. and Delrot, S. 2014. Berry ripening: recently heard through the grapevine. Journal of Experimental Botany 65. (16): 4543-4559. Doi: 10.1093/jxb/ert395

Li, C.H. and TAM, P.K.S. 1998. An iterative algorithm for minimum cross entropy thresholding. Pattern
Recognition Letters 18. (8): 771-776. Doi: 10.1016/ S0167-8655(98)00057-9

Longbottom, M.R. and Petrie, P.R. 2015. Role of vineyard practices in generating and mitigating greenhouse gas emissions. Australian Journal of Grape and Wine Research 21. (1): 522-536. Doi: 10.1111/ajgw.12197

Lórincz, A., Lukácsy, Gy. and Zanathy, G. 2003. A fürtritkítás hatása a szőlő teljesítményére I. A nemzetközi szakirodalom áttekintése (Impact of cluster thinning on grape productivity I. Overview of international litarature). Borászati Füzetek 13. (1): 1-10. (in Hungarian)

Marras, S., Masia, S., Duce, P., Spano, D. and Sirca, C. 2015. Carbon footprint assessment on a mature vineyard. Agricultural and Forest Meteorology 214 215. 350-356. Doi: 10.1016/j.agrformet.2015.08.270

Mathews, A.J. and Jensen, J.L.R. 2013. Visualizing and quantifying vineyard canopy LAI using an Unmanned Aerial Vehicle (UAV) collected high density structure from motion point cloud. Remote Sensing 5. (5): 2164-2183. Doi: 10.3390/rs5052164

Matthiasson, S. 2013. Yield and wine quality. Petaluma, CA, GuildSomm. Available at https://www.guildsomm.com/public_content/features/articles/b/a year_in_the_vineyard/posts/yields

Meissner, G., Athmann, M.E., Fritz, J., Kauer, R. Stoll, M. and Schultz, H.R. 2019. Conversion to organic and biodynamic viticultural practices: impact on soil, grapevine development and grape quality. OENO One 53. (4): 639-659. Doi: 10.20870/ oeno-one.2019.53.4.2470

NaOr, A., Gal, Y. and Bravdo, B. 2002. Shoot and cluster thinning influence vegetative growth, fruit yield, and wine quality of ,Sauvignon blanc' Grapevines. Journal of the American Society for Horticultural Science 127. (4): 628-634. Doi: 10.21273/ JASHS.127.4.628

Nendel, C. and Kersebaum, K.C. 2004. A simple model approach to simulate nitrogen dynamics in vineyard soils. Ecological Modelling 177. (1-2): 1-15. Doi: 10.1016/j.ecolmodel.2004.01.014

Nistor, E., Dobrei, A., Dobrei, Al., Camen, D., Sala, F. and Prundeanu, H. 2018. Nitrous oxide $\left(\mathrm{N}_{2} \mathrm{O}\right)$, $\mathrm{CO}_{2}$ production, and $\mathrm{C}$ sequestration in vineyards: a review. Water Air and Soil Pollution 229. (9): 1-9. Doi: 10.1007/s11270-018-3942-7

OIV 2009. Compendium of international methods of analysis. Quantification of total nitrogen according to the Dumas method. International Organization of Vine and Wine (OIV), Paris. 1-5. (Method OIV-MAAS323-02A) Available at http://www.oiv.int/public/ medias/2578/oiv-ma-as323-02a.pdf

Ojeda, H., Deloire, A. and Carbonneau, A. 2001. Influence of water deficits on grape berry growth. Vitis 40. 141-145.

Pádua, L., Adão, T., Sousa, A., Peres, E. and Sousa, J.J. 2020. Individual grapevine analysis in a multi- 
temporal context using UAV-based multi-sensor imagery. Remote Sensing 12. (1)139. Doi: 10.3390/ rs12010139

Probst, B., SchüLer, C. and Joergensen, R.G. 2008. Vineyard soils under organic and conventional management - microbial biomass and activity indices and their relation to soil chemical properties. Biology and Fertility of Soils 44. (3): 443-450. Doi: 10.1007/s00374-007-0225-7

Provost, C. and Pedneault, K. 2016. The organic vineyard as a balanced ecosystem: Improved organic grape management and impacts on wine quality. Scientia Horticulturae 208. 43-56. Doi: 10.1016/j. scienta.2016.04.024

Pucкetтe, M. 2016. Illustrated Grapevine Training Methods. Wine Folly. Available at https://winefolly.com/deep-dive/grape-vine-training-methodsillustration/

Regina, K. and HüprI, R. 2019. Soil greenhouse gas emissions. In Handbook of Plant and Soil Analysis for Agricultural Systems. Eds.: Álvaro-Fuentes, J., ThieleBruhn, S., Lóczy, D. and Zornoza, R., Cartagena, RAI Universidad Politécnica de Cartagena (UPCT), 149-151.

Richards, F.J. 1959. A flexible growth function for empirical use. Journal of Experimental Botany 10. (2): 290-301.

Riczu, P., Juhász, Cs. and Zsigrai, Gy. 2018. Spektrális távérzékelés lehetősége szőlő-ültetvények kondíciójának térképezésére (Opportunities for spectral remote sensing for mapping the condition of grape plantations). Tokaji Kutatóintézet, Szőlészeti és Borászati Kutató Nonprofit Kft. Szőló - Levél 8. (5): 4-7.

Rodrigo-Comino, J., Keesstra, S. and Cerdà, A. 2018. Soil erosion as an environmental concern in vineyards: The case study of Celler del Roure, Eastern Spain, by means of rainfall simulation experiments. Beverages 4. 31-42. Doi: 10.3390/beverages4020031

Sadras, V.O., Moran, M.A. and Bonada, M. 2013. Effects of elevated temperature in grapevine. Berry sensory traits. Australian Journal of Grape and Wine Research 19. 95-106. Doi: 10.1111/ajgw.12007

Semmens, K.A., Anderson, M.C., Kustas, W.P., GaO, F., Alfieri, J.G., McKee, L., Prueger, J.H., Hain, C.R., Cammaleri, C., Yang, Y., Xia, T., Sanchez, L., Alisna, M.M. and VéLez, M. 2016. Monitoring daily evapotranspiration over two California vineyards using Landsat 8 a multi-sensor data fusion approach. Remote Sensing and Environment 185. 155-170. Doi: 10.1016/j.rse.2015.10.025

Shrestha, A., Kurtural, S.K., Fidelibus, M.W., Dervishian, G. and Konduru, S. 2013. Efficacy and cost of cultivators, steam, or an organic herbicide for weed control in organic vineyards in the San Joaquin Valley of California. Horticultural Technology 23. 99-108.
Silvestroni, O., Lanari, V., Lattanzi, T. and Palliotti, A. 2018. Delaying winter pruning, after pre-pruning, alters budburst, leaf area, photosynthesis, yield and berry composition in Sangiovese (Vitis vinifera L.). Australian Journal of Grape and Wine Research 24. 478-486. Doi: 10.1111/ ajgw.12361

SMART, R. and Robinson, M. 1991. Sunlight into wine: A handbook for winegrape canopy management. Adelaide, Winetitles.

SteEnwerth, K.L. and Belina, K.M. 2008. Cover crops enhance soil organic matter, carbon dynamics and microbiological function in a vineyard agroecosystem. Applied Soil Ecology 40. (2): 359-369. Doi: 10.1016/j.apsoil.2008.06.006

TалIMA, R. and Като, Y. 2011. Comparison of threshold algorithms for automatic image processing of rice roots using freeware ImageJ. Field Crops Research 121. (3): 460-463. Doi: 10.1016/j.fcr.2011.01.015

Towers, P.C., Albert, S. and Poblete-Echeverría, C. 2019. Comparison of vegetation indices for Leaf Area Index estimation in vertical shoot positioned vine canopies with and without Grenbiule HailProtection Netting. Remote Sensing 11. (9):1073. Doi: 10.3390/rs11091073

Vilanova, M. and Soto, B. 2005. The impact of geographic origin on sensory properties of Vitis vinifera cv. Mencía. Journal of Sensory Studies 20. (6): 503-511. Doi: 10.1111/j.1745-459X.2005.00046.X

Werner, J. and Forgács, B. 2016. Ökológiai szőlőtermesztés a Villányi borvidékek, Gere Attila pincészeténél (Ecological viticulture in the Gere Attila Winery, Villány Wine District). Növényvédelem 77. (6): 332-336.

Whalley, J. and Shanmuganathan, S. 2013. Applications of image processing in viticulture: a review. Proceedings, $20^{\text {th }}$ International Congress in Modelling and Simulation, Adelaide, AUS, 1-6 December 2013. Adelaide, Modelling and Simulation Society of Australia and New Zealand (MSSANZ) Inc. 531-537.

Wilson, J.W. 1963. Estimation of foliage denseness and foliage angle by inclined point quadrats. Australian Journal of Botany 11. 95-105. Doi: 10.1071/ BT963 0095

WolfF, M., del mar Alsina, M. and Smart, D.R. 2013. Conservation tillage of cover crops in vineyard soils to improve carbon sequestration and diminish greenhouse gas emissions. Wines \& Vines 94. 84-92.

ZeIDE, B. 1993. Analysis of growth equations. Forest Science 39. (3): 594-616. Doi: 10.1093/forestscience/39.3.594 